\title{
Media Image of Parliamentary Elections in Poland in 2015
}

Book Review: Rafał Klepka, Medialna walka o dobrą zmianę. Obraz wyborów parlamentarnych w 2015 roku w wybranych mediach, Libron, Cracov 2018, pp. 204.

Media are powerful tools in political activities, especially in a period of electoral campaigns. Many researchers undertake studies on relations between media coverage and election results. It is not a simple task because many kinds of influence are invisible and informal. It is also difficult to unambiguously indicate what factors were meaningful for agenda-setting effect in given TV and radio stations, and newspapers.

Rafał Klepka undertook a difficult task of studying a way of presenting in media political competition during the electoral campaign in Poland in 2015. The author holds $\mathrm{PhD}$ degree in political science and is a lecturer at the Pedagogical University in Cracov. His scientific activity and interests focus on dependencies between media, standpoints, opinions, electoral behaviors and ways of presenting social phenomena in media (Klepka, 2018).

The reviewed book consists of an introduction, four main chapters and a summary. In the first chapter the author reviews theory on the studied matter, i.e. relations between media and politics, and the role of media as a source of information about politics. Unfortunately, beside the short mention in the introduction, the publication lacks references to works of authors associated with agenda-setting concept, such as Ewa Nowak (2014) or Bartłomiej Łódzki (2010), who were investigating exactly the same research subject as the author. Moreover, the reviewed work would greatly benefit if in the fragments on the category of presidentialization the author referred to Wojciech Peszyński’s article on the presidentialization of electoral behaviors (Peszyński, 2016, pp. 37-55). Instead, the author referred to the concept of the political partiality of media. The rest of the chapter had methodological 
remarks. The second one concerned elections in 2015, i.e. grounding a political campaign, its results and consequences in the social and political context. The other two chapters are strictly empirical. One of them includes an analysis of informational programmes, while the other consists of analyses of weekly published political-social newspapers.

Despite the interesting subject and the high degree of scientific solidity, the publication is not free from defects. First of all, the author faultily defined a research aim because the content analysis itself cannot be a goal (p. 11). It is a scientific method that can be further specified to a research technique corresponding to the selected types of sources. Then, the author enumerated secondary goals of the study among which there is finding the topic that is the most frequently present in media. In the remainder the author takes as an important goal "to assess the strength and direction of political partiality of studied media" (p. 11). A complicated and maybe even impossible task seems to be to study the strength of any influence, like the author would like to do. More probable seems to be an analysis of ideological profile, yet no in terms the author does so: "in the analysis of visibility of political parties in elections" (p. 11). Its classification as neutral, positive, negative or ambiguous will always be arbitrary. It requires from a researcher to be careful and diligent. The last goal indicated by the author is to answer a question about support that media grant to the process of parliamentary presidentialization of electoral campaign (p. 11). Secondary research problems were given in the more detailed form in the further part of the publication ( $\mathrm{p}$. 80) what was not necessarily fortunate act from the methodological perspective because it introduces an inconsistency to the work. Another flaw is that there are too many research problems which makes an impression that the author wanted to study everything. Of course, the research problems are interesting but for several, not one, works. Hypotheses correspond with the secondary research problems yet they were formulated vaguely (p. 81) especially in the context of used theoretical categories (e.g. plans for ruling at p. 81).

Another flaw is using the names of politicians which was done inconsistently throughout the book and without due respect to these persons (e.g. at p. 64), especially taking respectful chairs like presidential one, for instance.

The study's timeframe was not justified too weakly. Giving "two months after summer holidays" (p. 82) as a justification for choosing the temporal border of study cannot stand as a proper one. More appropriate would be choosing the formal date of beginning the electoral campaign. Second option could be choosing the beginning of year since politicians often begin electoral activities before the official start of the campaign.

In the further part of the book the author analyzing the gathered empirical data, used the so-called news positioning in audition structure (p.93). In this case the author should apply the agenda-setting methodology which is much more appropriate for studying a news position in daily agendas. In the empirical part of the work one can find a distinction into four forms of politicians' activities in news programmes and vague formulation about the highest visibility (p. 103). Doubts may be raised also by the distinction to: giving a name, quoting a line, presenting a person and her speech (p. 103). Although one can figure out what is the 
difference between presenting a speech and its quoting, the author should indicate distinctive features for each criterion. In such a way the author would avoid misunderstandings.

The publication Medialna walka o dobrą zmianę. Obraz wyborów parlamentarnych $w 2015$ roku w wybranych mediach is a position that is worth reading because it presents the role of media in creating standpoints, behaviors and opinions during an electoral campaign. The author made a detailed analysis of media coverage and gathered impressive amounts of empirical data. Minor flaws of the work do not have a greater meaning for the general assessment of the book. This is a position that should be read by every scholar interested in communication and political sciences.

\section{References}

Łódzki, B. (2010). Ustanawianie agendy mediów podczas kampanii wyborczych w 2005 roku. Wrocław: Wydawnictwo Uniwersytetu Wrocławskiego.

Nowak, E. (2014). Ustanawianie agendy politycznej przez media. Efekt newsa w Polsce. Lublin: Wydawnictwo Uniwersytetu Marii Curie-Skłodowskiej.

Peszyński, W. (2016). Prezydencjalizacja zachowań wyborczych w elekcji parlamentarnej w 2015 roku. Political Preferences, No. 12, pp. 37-55.

\section{Author}

\section{Kamila Rezmer-Płotka}

kamila.rezmer@onet.pl - Nicolaus Copernicus University (Poland) 
